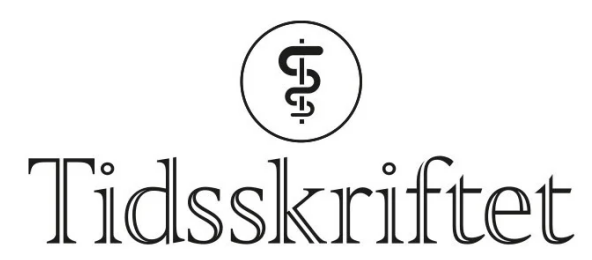

DEN NORSKE LEGEFORENING

\title{
Livssyn og helsearbeid
}

\author{
ANMELDELSER
}

\section{ARE HOLEN}

Professor emeritus, Institutt for psykisk helse NTNU

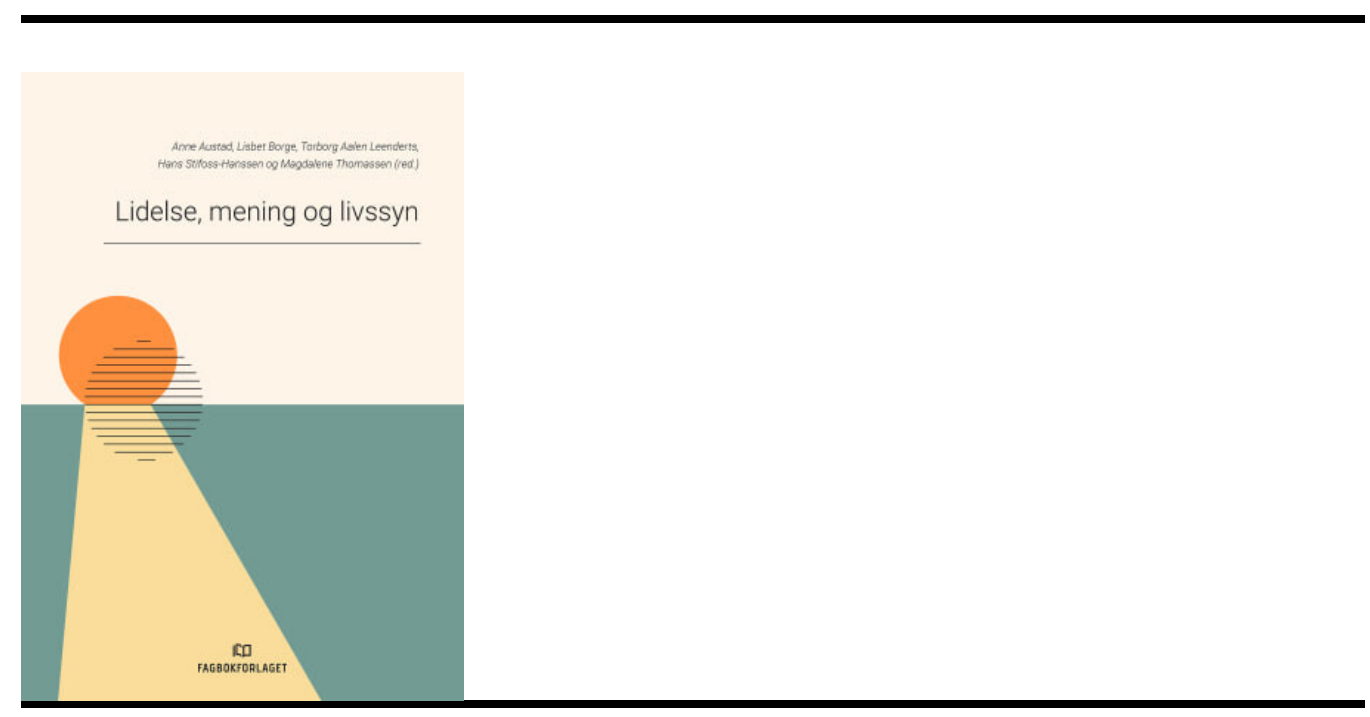

Anne Austad, Lisbet Borge, Torborg Aalen Leenderts et al., red.

Lidelse, mening og livssyn

273 s. Bergen: Fagbokforlaget, 2020. Pris NOK 369

ISBN 978-82-450-2409-8

Norge er ikke lenger et kulturelt og livssynsmessig homogent samfunn. Særlig i helsesektoren møter man stadig personer med ulike kultur- og livssynstradisjoner. I pasientarbeid legges det nå vekt på pasientsentrert behandling. Pasientene skal bli møtt på deres egne premisser. Det er behandlerens oppgave å komme slike forventninger i møte. Flere offentlige utredninger har fremholdt pasienters rett til å praktisere sitt livssyn og bli respektert for det.

Innledningsvis i boken understrekes det at sykdom, krise og nød ofte bringer frem pasienters klare behov for å snakke om eksistensielle tema. Samtidig påpeker den at undervisning om og holdninger til ulike livssyn gjerne har manglet i nåværende 
helseutdanninger. Idealet har lenge vært verdinøytralitet. Det kan ha ført til en unødvendig verdiblindhet, fremsettes det i boken.

Livssynsbegrepet som benyttes, favner ganske vidt. Det dekker spørsmål knyttet til meningen med livet og ikke minst lidelsen. I egne kapitler omtales ulike forståelsesmåter ved bl.a. jødiske, kristne, islamske, sekulær-humanistiske og buddhistiske retninger, men også mindfulness, nyåndelige og alternative bevegelser samt samiske tradisjoner. Kapitlene er skrevet av personer med fordypet innsikt i de livssynene som presenteres, men forfatterne har ikke alltid selv det livssynet de omtaler. Samlet gir boken en interessant og opplysende oversikt. Den kan bidra til en utvidet relasjonskompetanse og dermed et bedre utgangspunkt for å møte hjelpsøkende personer også på livssynsområdet.

Redaksjonen tilhører VID vitenskapelige høgskole, som er orientert mot helseutdanninger og livssynsspørsmål. Målet er ikke at den som jobber i helsevesenet skal være sjelesørger, men ha tilstrekkelig bakgrunn til å være en god lytter og eventuelt kunne kanalisere videre pasientens behov på livssynsområdet. Boken er ikke direkte praktisk rettet, men den gir en allmenn bakgrunnsforståelse for de ulike livssynsvariasjoner som man i dag kan møte ved arbeid innen helse og omsorg.

Publisert: 3. mai 2021. Tidsskr Nor Legeforen. DOI: 10.4045/tidsskr.21.0162

(C) Tidsskrift for Den norske legeforening 2023. Lastet ned fra tidsskriftet.no 26. april 2023. 